\title{
Necrotizing pneumonia complicated by early and late pneumatoceles
}

\author{
Suhail Al-Saleh MBBS FRCPC ${ }^{1}$, Hartmut Grasemann MD ${ }^{1}$, Peter Cox MD²
}

\begin{abstract}
S Al-Saleh, H Grasemann, P Cox. Necrotizing pneumonia complicated by early and late pneumatoceles. Can Respir J 2008;15(3):129-132.

Community-acquired pneumonia generally has a benign course when treated, but can be complicated by pleural effusion, empyema, lung abscesses, necrotizing pneumonia or pneumatoceles. Pneumatoceles can cause cardiorespiratory compromise requiring urgent intervention. A child with a severe necrotizing pneumonia, as well as a large early pneumatocele complicating mechanical ventilation, is presented. While pneumonectomy resulted in transient improvement, the course was further complicated by multiple late occurring pneumatoceles that ultimately led to the patient's death.
\end{abstract}

Key Words: Children; Community-acquired pneumonia; Complicated pneumonia

\section{CASE PRESENTATION}

A three-year-old girl born in Canada, whose family was originally from eastern Europe, had an unremarkable medical history except for febrile and nonfebrile seizures. Her immunization was up to date, including the conjugated pneumococcal vaccine (three doses of Prevnar [Wyeth Pharmaceuticals Inc, USA]). She had no tuberculosis contact, and her family history was negative for respiratory, immune or genetic diseases.

The girl presented with a four-day history of fever, lethargy and decreased oral intake. She had no history of upper or lower respiratory symptoms, and was started on amoxicillin two days before hospital admission. On the day of admission, she developed a cough, shortness of breath and grunting. Her physical examination revealed a heart rate of 160 beats/min, respiratory rate of 44 breaths $/ \mathrm{min}$, temperature of $37.7^{\circ} \mathrm{C}$ and peripheral $\mathrm{O}_{2}$ saturation of $93 \%$ on $50 \% \mathrm{O}_{2}$. Her chest examination revealed bilaterally decreased air movement and diffuse crackles. Chest x-ray on admission showed right upper lobe (RUL), right middle lobe and left lower lobe air space disease (Figure 1). At that time, blood cultures were performed and intravenous (IV) cefuroxime $(150 \mathrm{mg} / \mathrm{kg} /$ day $)$ was commenced. Venous blood work showed a $\mathrm{pH}$ of 7.25 , partial pressure of $\mathrm{CO}_{2}$ $\left(\mathrm{pCO}_{2}\right)$ of $44 \mathrm{mmHg}, \mathrm{HCO}_{3}$ concentration of $18 \mathrm{mmol} / \mathrm{L}$, base excess of $18 \mathrm{mmol} / \mathrm{L}$, white blood cell count of $5.5 \times 10^{9} / \mathrm{L}(21 \%$ left shift), hemoglobin level of $125 \mathrm{~g} / \mathrm{L}$ and platelet count of $169 \times 10^{9} / \mathrm{L}$.

\section{Une pneumonie nécrosante compliquée par des pneumocèles précoces et tardifs}

\begin{abstract}
La pneumonie non nosocomiale a généralement une évolution bénigne lorsqu'elle est traitée, mais elle peut être compliquée par une effusion pleurale, un empyème, des abcès pulmonaires ou des pneumocèles. Les pneumocèles peuvent compromettre la fonction cardiopulmonaire et exiger une intervention urgente. Est présenté le cas d'un enfant atteint d'une pneumonie nécrosante grave accompagnée d'un vaste pneumocèle précoce compliquant une ventilation mécanique. Une exérèse pulmonaire a favorisé une amélioration transitoire, mais l'évolution a été compliquée par de multiples pneumocèles tardifs qui ont fini par entraîner le décès de la patiente.
\end{abstract}

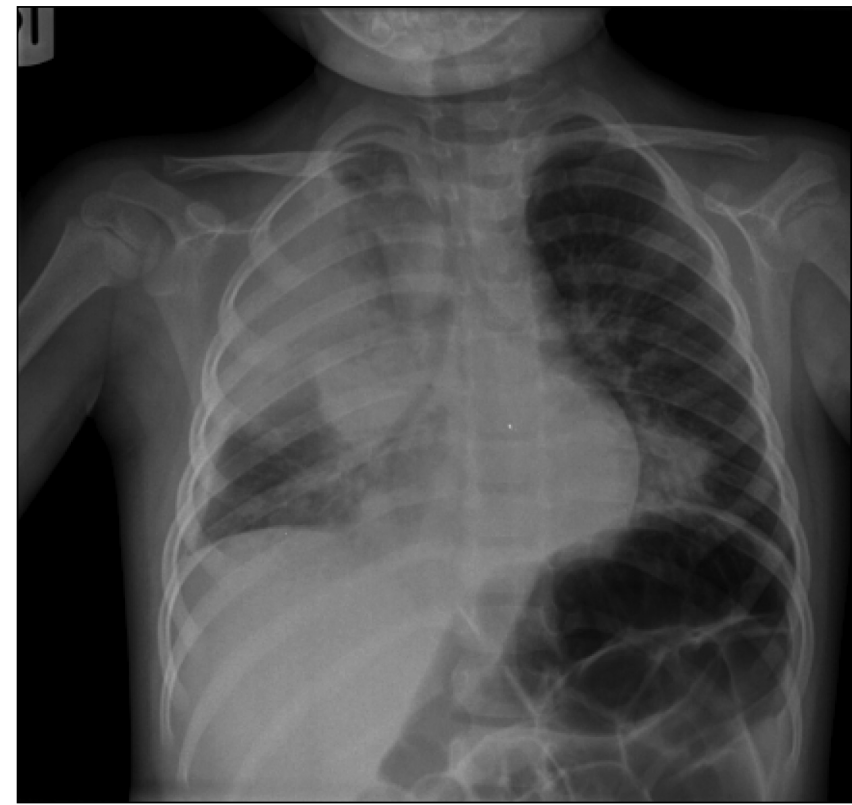

Figure 1) Chest radiograph on admission showing left lower lobe, right middle lobe and right upper lobe consolidation

On day 1 of admission, the patient was transferred to the critical care unit for respiratory distress, increasing $\mathrm{O}_{2}$ requirement

\footnotetext{
${ }^{1}$ Division of Respiratory Medicine; ${ }^{2}$ Division of Critical Care Medicine, The Hospital for Sick Children, Toronto, Ontario

Correspondence: Dr Suhail Al-Saleh, The Hospital for Sick Children, 555 University Avenue, Toronto, Ontario M5G 1 X8.

Telephone 416-813-6346, fax 416-813-6246, e-mail suhail.al-saleh@sickkids.ca
} 

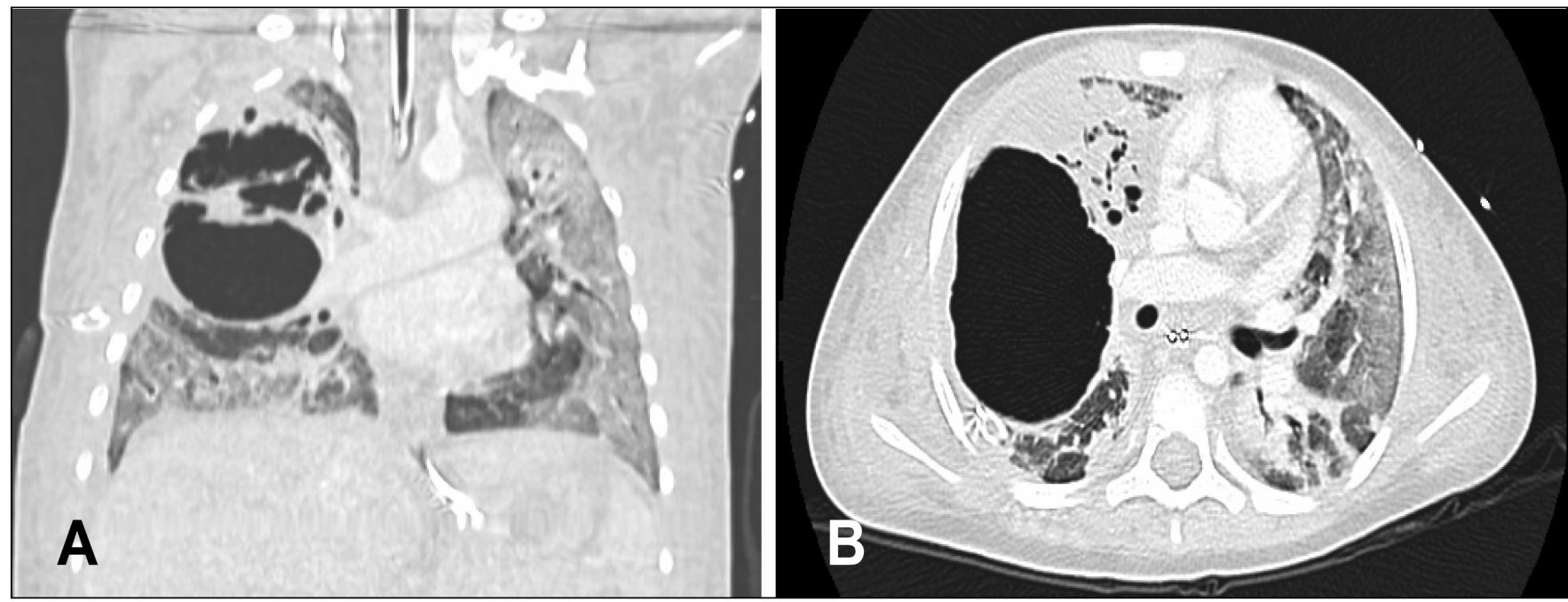

Figure 2) Computed tomography images of the chest showing bilateral air space disease and a large right upper lobe pneumatocele. A Coronal view. B Transverse view

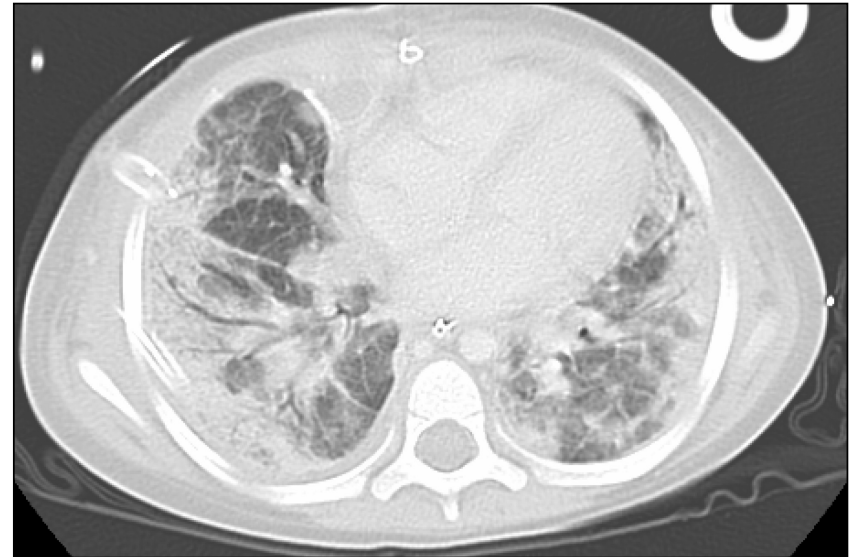

Figure 3) Computed tomography image of the chest postsurgery, showing bilateral infiltrations but no cysts

(saturation $82 \%$ to $85 \%$ on $100 \% \mathrm{O}_{2}$ ) and signs of septic shock. Her respiratory status further deteriorated requiring intubation. Initial conservative ventilation was switched to high-frequency oscillatory (HFO) ventilation (oxygenation index 55). She was treated with fluid boluses, as well as blood product transfusions, and received inotropic support for hemodynamic instability. Broad spectrum IV antibiotic coverage was added (clindamycin $30 \mathrm{mg} / \mathrm{kg} /$ day, cefotaxime $100 \mathrm{mg} / \mathrm{kg} / \mathrm{day}$, vancomycin $40 \mathrm{mg} / \mathrm{kg} /$ day adjusted according to blood levels to $25 \mathrm{mg} / \mathrm{kg} / \mathrm{day}$, and ciprofloxacin $20 \mathrm{mg} / \mathrm{kg} /$ day), which were all given for a total of two weeks. Broad spectrum antibiotic coverage was initiated in response to the critical status of the patient but in the absence of identified pathogens. As part of the management of acute respiratory distress syndrome, she was given methylprednisolone $(2 \mathrm{mg} / \mathrm{kg} /$ day as initial dose, tapered over two weeks), two doses of surfactant ( $60 \mathrm{~mL}$ over $1 \mathrm{~h}$ via endotracheal tube) and IV immunoglobulins $(1 \mathrm{~g} / \mathrm{kg})$.

Chest $\mathrm{x}$-ray on day 3 showed worsening of the previously noted consolidations and increased RUL lucencies. Arterial blood work at that time revealed a $\mathrm{pH}$ of $7.20, \mathrm{pCO}_{2}$ of $39 \mathrm{mmHg}$, partial pressure of $\mathrm{O}_{2}$ of $88 \mathrm{mmHg}, \mathrm{HCO}_{3}$ concentration of $15 \mathrm{mmol} / \mathrm{L}$, base excess of $12 \mathrm{mmol} / \mathrm{L}$, white blood cell count of $8.3 \times 10^{9} / \mathrm{L}$ (53\% left shift), hemoglobin level of
$102 \mathrm{~g} / \mathrm{L}$, platelet count of $41 \times 10^{9} / \mathrm{L}$, international normalized ratio (INR) of 1.2 , activated partial thromboplastin time (APTT) of $28 \mathrm{~s}$, and D-dimer concentration of $844 \mu \mathrm{g} / \mathrm{L}$.

On day $6, \mathrm{pCO}_{2}$ increased to $199 \mathrm{mmHg}$ while the patient was still ventilated with $\mathrm{HFO}$ using the following settings: $\Delta \mathrm{P}$ $85 \mathrm{~cm} \mathrm{H} \mathrm{H}_{2} \mathrm{O}$, mean airway pressure $31 \mathrm{~cm} \mathrm{H}_{2} \mathrm{O}$, frequency $9 \mathrm{~Hz}$ and $80 \% \mathrm{O}_{2}$ (oxygenation index 20 to 30 ). Imaging revealed extensive bilateral air space disease and a large air-filled cyst in the RUL surrounded by smaller cysts (Figure 2). HFO was switched to conventional ventilation using the following settings: peak inspiratory pressure $36 \mathrm{~cm} \mathrm{H}_{2} \mathrm{O}$, positive endexpiratory pressure $15 \mathrm{~cm} \mathrm{H}_{2} \mathrm{O}$, respiratory rate 35 breaths/min and $100 \% \mathrm{O}_{2}$ on day 7 . This resulted in a decrease of $\mathrm{pCO}_{2}$ to $88 \mathrm{mmHg}$, but because of persistent hypoxemia and hypercapnea, lobectomy of the RUL was performed on day 7 . Histopathology of the resected lung showed a picture of suppurative necrotizing pneumonia. Microbiology cultures of the resected tissue were negative, as were all previous cultures from throat swabs, tracheal aspirates, pleural fluid and blood. Immunology workup, including immunoglobulins and complement (C3, C4, and $\mathrm{CH} 50)$, was normal, and HIV status was negative.

High ventilatory pressures with a maximum positive endexpiratory pressure of $15 \mathrm{~cm} \mathrm{H}_{2} \mathrm{O}$ and peak pressure of $35 \mathrm{~cm} \mathrm{H} \mathrm{H}_{2} \mathrm{O}$ was needed for the first $4 \mathrm{~h}$ postsurgery to keep peripheral $\mathrm{O}_{2}$ saturation above $92 \%$. On day 11 , repeated computed tomography $(\mathrm{CT})$ scan of the chest postsurgery showed no large cysts (Figure 3 ).

In the postoperative course, the patient improved and ventilatory pressures were weaned before extubation on day 19 . Chest $\mathrm{x}$-ray one day before extubation showed no large cysts (Figure 4). When transferred to the ward on day 21, she had a baseline tachypnea of 40 breaths/min to 50 breaths/min and required $\mathrm{O}_{2}$ at $2 \mathrm{~L} / \mathrm{min}$ via nasal prongs. The child was otherwise doing well. Blood gas showed a $\mathrm{pCO}_{2}$ of $31 \mathrm{mmHg}$.

On day 24, respiratory rates increased to 60 breaths $/ \mathrm{min}$, and $\mathrm{O}_{2}$ requirement progressively increased on day 25 . Chest examination revealed decreased air movement on the right side. Chest $\mathrm{x}$-ray and CT at that time showed multiple large air-filled cysts, with hyperinflation on the right side resulting in mediastinal shift to the left (Figure 5). The patient was 


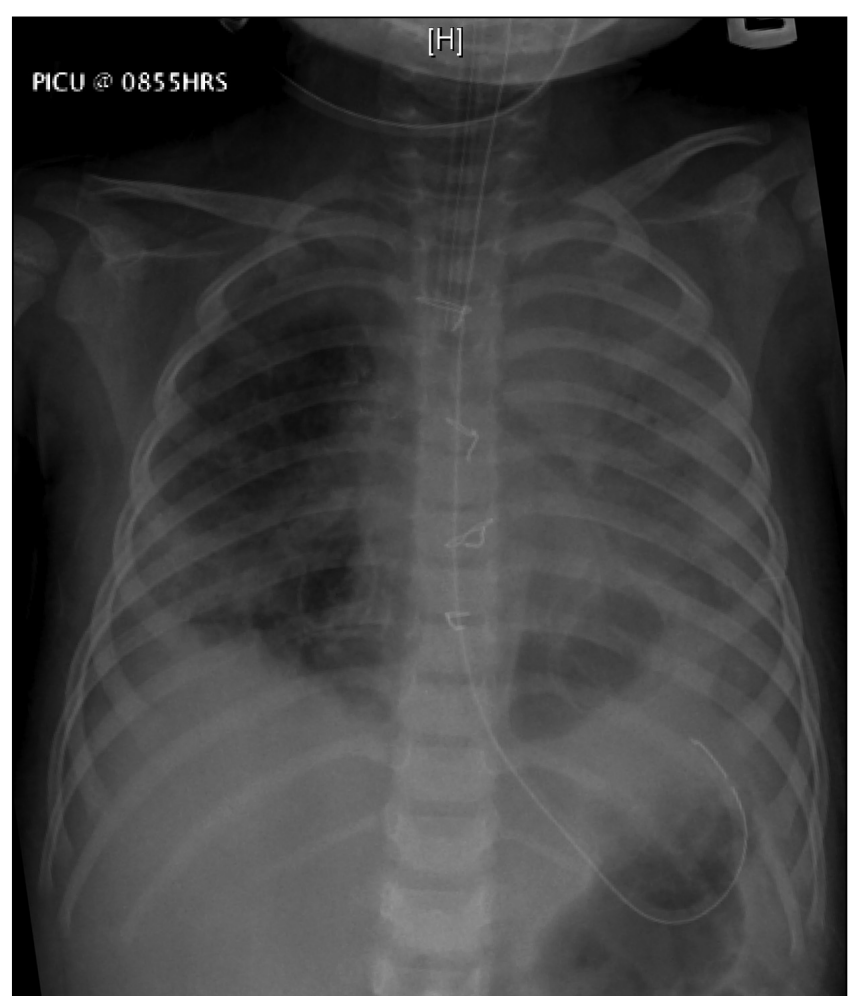

Figure 4) Chest radiograph before extubation shows consolidation of the left lung and some aeration of the right lung, but no evidence of large pneumatoceles

transferred back to the critical care unit on day 25. A conservative approach was initially attempted given the risk of intubation and positive pressure ventilation. However, when $\mathrm{O}_{2}$ saturation decreased dramatically, the decision was made for intubation. Recognizing the extremely high risk of the procedure, left main stem intubation was attempted to selectively ventilate the left lung. However, the patient arrested with bradycardia progressing to asystole during the procedure. Aggressive cardiac resuscitation was not pursued because ventilation was not possible. Her parents were fully apprised of the situation. The patient unfortunately died.

On autopsy, pulmonary hemorrhage and multiple pleural adhesions were seen on the right side. The diagnosis of suppurative pneumonitis was confirmed in the left lung but cultures for microbiology were again negative.

\section{DISCUSSION}

The incidence of community-acquired pneumonia in children is estimated to be $3 \%$ to $4 \%$ (1).

Although the clinical course of pneumonia is generally benign and responds well to conventional treatment, complications, including pleural effusion or empyema, lung abscesses or necrotizing pneumonia $(2,3)$ can occur. Complicated pneumonias in children are most commonly caused by bacterial pathogens, such as Streptococcus pneumoniae and Staphylococcus aureus (2), but cultures are reported to be negative in $45 \%$ to $89 \%$ of cases $(3)$.

Necrotizing pneumonia, also called massive pulmonary gangrene, is characterized by necrosis of consolidated lung tissue. Depending on the severity and the distribution, necrotizing pneumonia may be complicated by solitary, multiple or multiloculated radiolucent foci, bronchopleural fistulae and
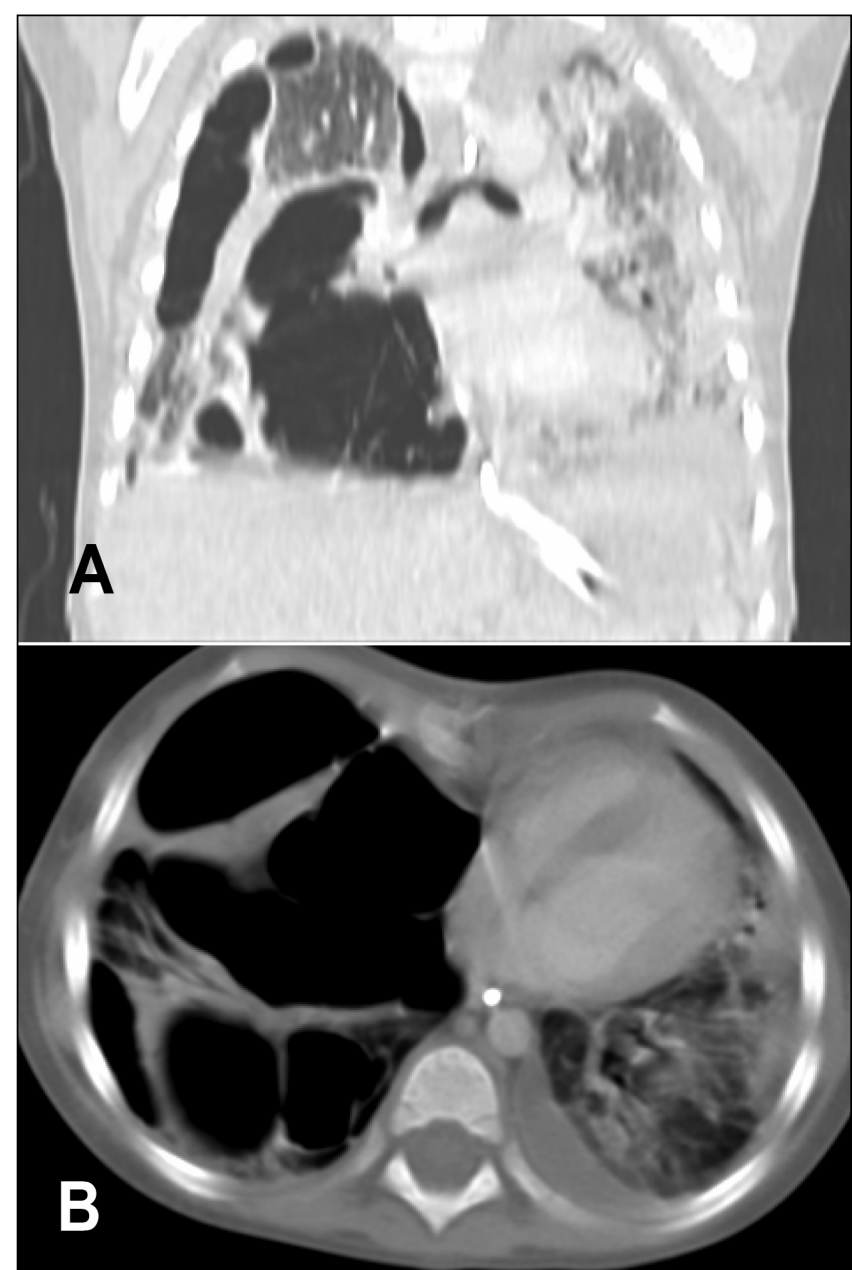

Figure 5) Computed tomography images of the chest showing multiple large air-filled cysts on the right side associated with mediastinal shift. A Coronal view. B Transverse view

intrapulmonary abscesses. The majority of cases involved one lobe; few reported cases involved more than one lobe $(4,5)$.

Pneumatoceles are thin-walled, air-filled intraparenchymal cysts that develop secondary to localized bronchiolar and alveolar necrosis, which allow one-way passage of air into the interstitial space (6). They occur in approximately $2 \%$ to $8 \%$ of hospitalized children with pneumonia (2). They commonly occur in immunocompetent patients (5), and are most commonly associated with $S$ aureus and $S$ pneumoniae infections $(4,5)$. Although there is no clear correlation between the development of pneumatoceles and mechanical ventilation, patients receiving mechanical ventilation have an increased risk for developing complications related to pneumatoceles, including an increase in their size (7). Other than in hyperimmunoglobulin E syndrome, there is no known genetic or familial tendency for pneumatoceles. Our case is representative of complicated community-acquired pneumonia in an immunocompetent patient, because she was previously healthy, had a normal previous chest $\mathrm{x}$-ray and had no evidence of immunological, anatomical, genetic or connective tissue disease.

The majority of pneumatoceles (more than 85\%) resolve spontaneously, partially or completely over weeks to months without clinical or radiographic sequelae $(2,8)$. 
The one-way passage of air can increase the pressure inside the pneumatocele, resulting in distension. Subsequent compression of the adjacent areas may cause cardiorespiratory compromise (ie, tension pneumatocele). Another complication of a tension pneumatocele is rupture through the pleural space and subsequent pneumothorax and/or bronchopleural fistulae. Pneumatoceles can also be complicated by secondary infection.

Our patient presented with extensive bilateral necrotizing pneumonia (picture of pulmonary sepsis) and early development of a large pneumatocele in the RUL that complicated mechanical ventilation. High-pressure ventilation resulted in ventilation of the pneumatocele - which is essentially dead space - tension effects of the pneumatocele on the adjacent lung tissue, as well as $\mathrm{CO}_{2}$ retention and difficulties in oxygenation. There was mild improvement with switching ventilation mode from $\mathrm{HFO}$ to conventional ventilation, which was in contrast to a case reported by Shen et al (9). Their report showed improvement of a patient with tension pneumatocele after using $\mathrm{HFO}$ ventilation.

In our patient, the decision was made to perform lobectomy as a life-saving emergency procedure to relieve the tension effect on the remainder of the lung because there was no feasible alternative. Lobectomy resulted in a dramatic improvement in the patient's ventilation. Other reports indicated that lobectomy was helpful in similar cases (10-13), but in these reports, lobectomy or pneumonectomy was performed either in patients with multiple tension pneumatoceles (10-12) or in patients with single tension pneumatocele after failure of chest

\section{REFERENCES}

1. Jokinen C, Heiskanen L, Juvonen H, et al. Incidence of community-acquired pneumonia in the population of four municipalities in eastern Finland. Am J Epidemiol 1993;137:977-88.

2. Kunyoshi V, Cataneo DC, Cataneo AJ. Complicated pneumonias with empyema and/or pneumatocele in children. Pediatr Surg Int 2006;22:186-90.

3. Tan TQ, Mason EO Jr, Wald ER, et al. Clinical characteristics of children with complicated pneumonia caused by Streptococcus pneumoniae. Pediatrics 2002;110:1-6.

4. Chen KC, Su YT, Lin WL, Chiu KC, Niu CK. Clinical analysis of necrotizing pneumonia in children: Three-year experience in a single medical center. Acta Paediatr Taiwan 2003;44:343-8.

5. Hsieh $\mathrm{YC}, \mathrm{Hsiao} \mathrm{CH}$, Tsao PN, et al. Necrotizing pneumococcal pneumonia in children: The role of pulmonary gangrene. Pediatr Pulmonol 2006;41:623-9.

6. Quigley MJ, Fraser RS. Pulmonary pneumatocele: Pathology and pathogenesis. AJR Am J Roentgeol 1988;150:1275-7.

7. Amitai I, Mogle P, Godfrey S, Aviad I. Pneumatocele in infants and children. Report of 12 cases. Clin Pediatr (Phila) 1983;22:420-2.

8. Imamoğlu M, Cay A, Koşucu P, et al. Pneumatoceles in postpneumonic empyema: An algorithmic approach. J Pediatr Surg 2005;40:1111-7. drain $(12,13)$. We were unable to find any similar cases of lobectomy for an isolated undrained tension pneumatocele in the literature. CT-guided catheter drainage, reported by others as a successful management of early tension pneumatoceles $(8,14,15)$, was not performed in our patient because she was at risk for complications from this procedure related to the high ventilatory pressure settings needed.

In our patient, multiple loculated tension pneumatoceles or pneumothoraces were seen on imaging later in the course, which were not evident in the first week of hospitalization. The observation that pneumatoceles were not seen in CT imaging immediately postsurgery suggests that they developed while the patient was spontaneously breathing. These pneumatoceles increased in size during the fourth week of hospitalization after antibiotic treatment and in the absence of active infection. Late development of pneumatoceles has been described after acute pneumonia even without an active inflammatory process (16), and during spontaneous breathing without the effect of positive pressure ventilation $(11,15)$. There are a few pediatric case reports similar to our case that were managed by needle aspiration and/or resection of the pneumatoceles $(11,15)$. However, in these cases there was limited lung injury and fewer pneumatoceles. As a preterminal event, selective left main stem bronchus intubation was attempted. This was to no avail and the patient had cardiopulmonary arrest during the procedure. Needle drainage was not attempted because the chest was filled with pneumatoceles; therefore, the procedure was assessed to be too risky.

9. Shen HN, Lu FL, Wu HD, Yu CJ, Yang PC. Management of tension pneumatocele with high-frequency oscillatory ventilation. Chest 2002;121:284-6.

10. Hodina M, Hanquinet S, Cotting T, Schnyder P, Gudinchet F. Imaging of cavitary necrosis in complicated childhood pneumonia. Eur Radiol 2002;12:391-6.

11. Wu ET, Chen JS. Management of multiple tension pneumatoceles refractory to tube thoracostomy decompression. Ann Thorac Surg 2006;81:1482-4.

12. Sinzobahamvya N. Emergency pulmonary resection for pneumonia. High mobidity and mortality. Scand J Thorac Cardiovasc Surg 1991;25:69-71.

13. Wu MH, Tseng YL, Lin MY, Lai WW. Surgical treatment of pediatric lung abscess. Pediatr Surg Int 1997;12:293-5.

14. Zuhdi MK, Spear RM, Worthen HM, Peterson BM. Percutaneous catheter drainage of tension pneumatocele, secondarily infected pneumatocele, and lung abscess in children. Crit Care Med 1996;24:330-3.

15. Aslan Y, Orhan F, Dinç H, Soylu H, Erduran E. Occult pneumococcal septicemia and pneumococcal pneumonia complicating pneumatoceles in a previously healthy child. Turk J Pediatr 1998;40:441-5.

16. Flaherty RA, Keegan JM, Sturtevant HN. Post-pneumonic pulmonary pneumatoceles. Radiology 1960;74:50-3. 


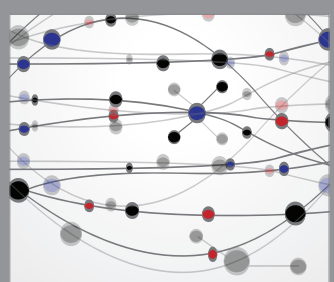

The Scientific World Journal
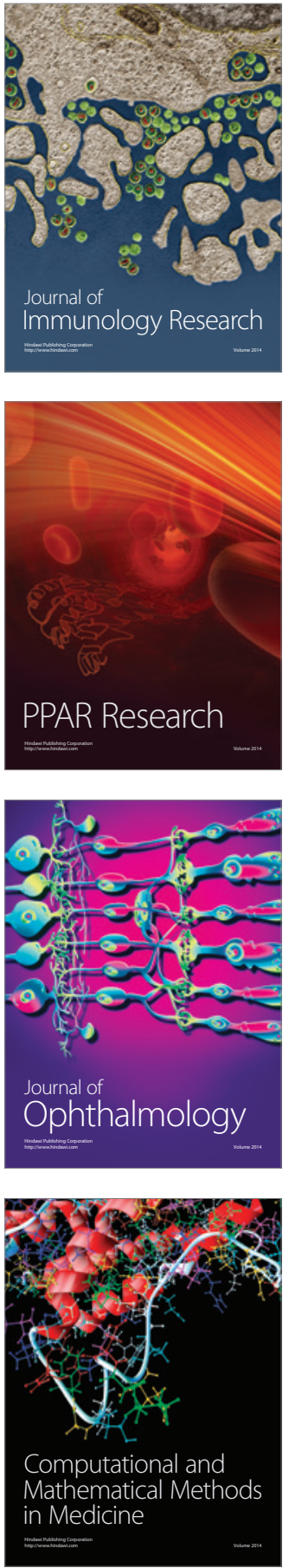

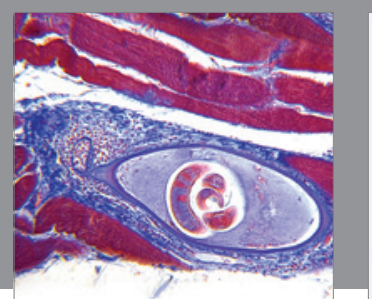

Gastroenterology Research and Practice

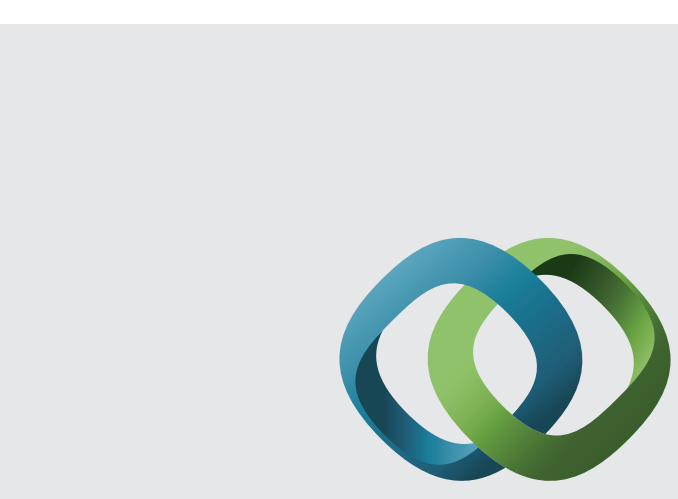

\section{Hindawi}

Submit your manuscripts at

http://www.hindawi.com
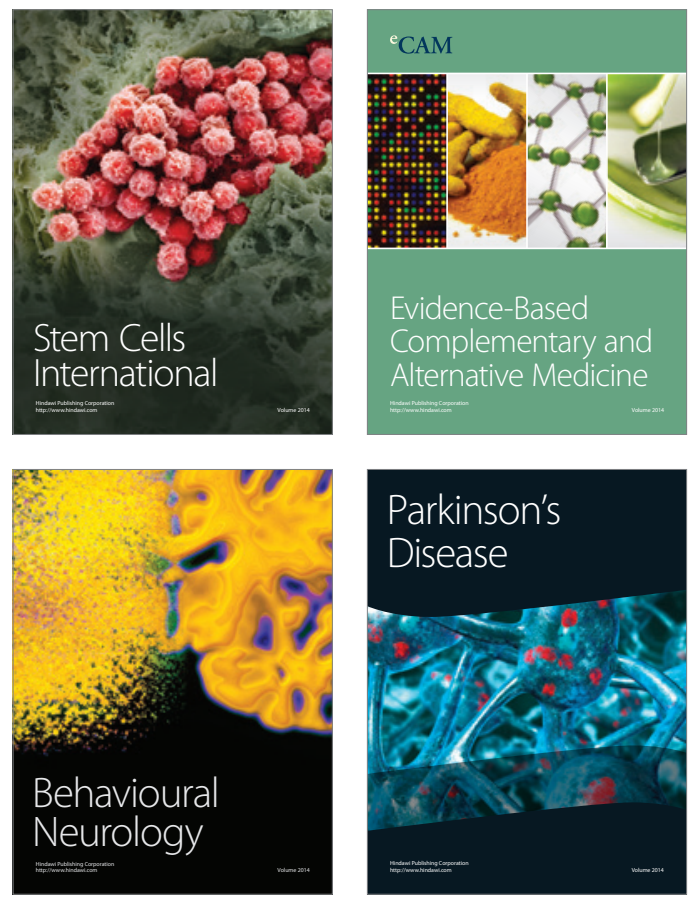
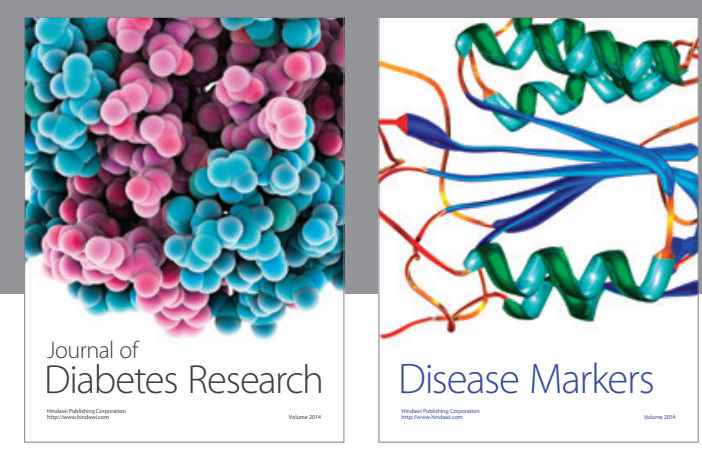

Disease Markers
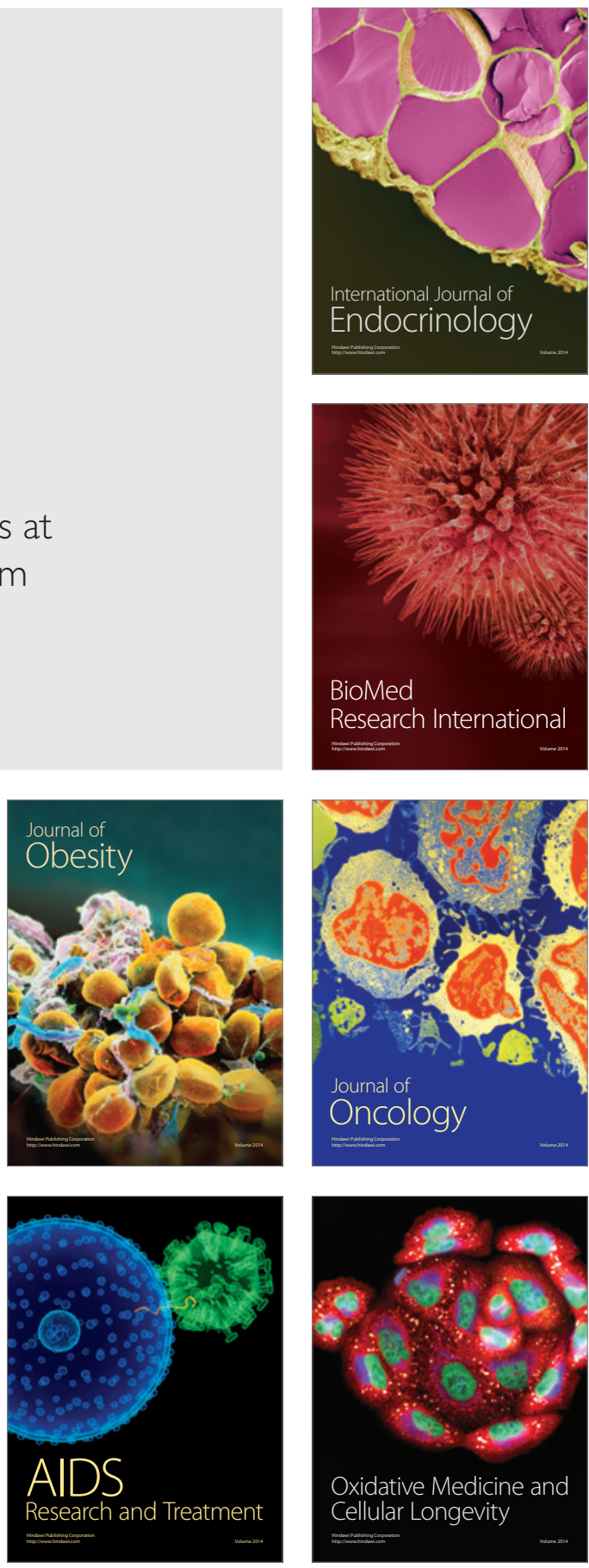